\title{
KARAKTERISTIK INDIVIDU, KARAKTERISTIK PEKERJAAN DAN KINERJA KARYAWAN YANG DIMEDIASI OLEH MOTIVASI KERJA PADA PEMBATIK PUTTING OUT SYSTEM
}

\author{
Ike Agustina1, Hardani Widhiastuti ${ }^{2}$ \\ 1,2Magister Psikologi Universitas Semarang \\ Jl. Soekanrno Hatta, Tlogosari Kulon, Kec. Pedurungan, Semarang, Jawa Tengah 59160 \\ e-mail:1ike.titin@gmail.com, 2dhanifpsi@usm.ac.id
}

Article History:

Received

Review

25 Mei 2021

Revised

19 Juni 2021

Accepted

Published

23 Juni 2021

Reviewer A:

Muhammad Abd Hadi Bunyamin
18 Mei 2021

20 Juni 2021

Abstract.Performance improvement is influenced by several factors, one of which is individual characteristics, job characteristics and work motivation. Individuals who have high motivation at work will trigger the power and potential to work better and productively so that the resulting performance will increase and quality.The aims of this research were to determine the effect of individual characteristics and job characteristics on performance through work motivation. This research uses quantitative methods with incidental sampling techniques, totaling 66 batik people in Central Java. Hypothesis testing uses path analysis techniques processed with the SmartPLS 3.0 program. The results showed that 1) individual characteristics had a positive and significant effect on work motivation; 2) job characteristics have a positive and significant effect on work motivation; 3) work motivation has a positive and significant effect on performance; 4) individual characteristics are not significant to performance; 5) job characteristics have a positive and significant effect on performance.

Keywords: Individual Characteristics, Job Characteristics, Work Motivation, Employee performance

Abstrak. Tujuan dari penelitian ini adalah untuk mengetahui pengaruh karakteristik individu, karakteristik pekerjaan terhadap kinerja melalui motivasi kerja. Penelitian ini menggunakan metode kuantitatif dengan teknik pengambilan sampling insidental, berjumlah 66 orang pembatik di Jawa Tengah. Pengujian hipotesis menggunakan teknik analisis jalur yang diolah dengan program SmartPLS 3.0. Hasil penelitian menunjukkan bahwa 1) kakarteristik individu berpengaruh positif dan signifikan terhadap motivasi kerja; 2) karakteristik pekerjaan berpengaruh positif dan signifikan terhadap motivasi kerja; 3) motivasi kerja berpengaruh positif dan signifikan terhadap kinerja; 4) karakteristik individu tidak signifikan terhadap kinerja; 5) karakteristik pekerjaan berpengaruh positif dan signifikan terhadap kinerja.

Kata Kunci: Karakteristik Individu, Karakteristik Pekerjaan, Motivasi Kerja, Kinerja

\section{Pendahuluan}

Perkembangan dan kemajuan suatu organisasi tidak dapat dipungkiri jika faktor manajemen SDM memberi pengaruh sebagai driven force (kekuatan mendorong) yang mampu memberi percepatan kearah masa depan. Perkembangan yang terjadi dalam suatu 
perusahaan memberikan tantangan bagi organisasi agar mampu dalam melakukan penyesuaian terhadap segala perubahan dan perkembangan yang terjadi. Sumber Daya Manusia (SDM) menjadi faktor penting dalam sebuah organisasi. Hal ini dikarenakaan segala aktifitas suatu organisasi dijalankan oleh karyawan atau sumber daya manusia, sehingga perusahaan memerlukan sumber daya manusia yang memiliki potensi yang mampu menghasilkan kinerja yang diharapkan organisasi ( A'syah dan Suhaeli, 2020 ). Kinerja karyawan dipersepsikan dengan hasil pekerjaan yang mempunyai hubungan kuat dengan tujuan strategis organisasi dan memberikan kontribusi ekonomi. Lebih jauh Fahmi (2016:137) menyatakan bahwa kinerja pada umumnya sebagai kesuksesan seseorang dalam melaksanakan suatu pekerjaan. Kinerja karyawan sebagai salah satu faktor penentu keberhasilan perusahaan atau organisasi dalam mencapai tujuannya.

Seiring dengan perkembangan ilmu pengetahuan dan teknologi yang semakin canggih, perusahaan semakin menginginkan usahanya berjalan dengan baik dan mendapatkan keuntungan yang maksimal. Perusahaan juga tidak dapat menghindari persaingan industri yang semakin maju dan ketat. Sebuah perusahaan harus mampu memanfaatkan sumber daya yang dimiliki secara optimal. Salah satunya adalah dengan meningkatkan kualitas sumber daya manusianya.

Hal yang harus dilakukan perusahaan adalah dengan memiliki manajemen sumber daya manusia yang mampu menciptakan kondisi yang mendorong dan memungkinkan karyawan untuk mengembangkan kualitas karyawan yang dimiliki. Manajemen sumber daya manusia juga sangat dibutuhkan keberadaannya oleh perusahaan untuk dapat menangani berbagai masalah-masalah yang berkaitan dengan para karyawannya. Hal ini diperkuat oleh pendapat (Dilip Bhatt, 2000) dalam Amir (2015:93), perusahaan harus menginvestasikan sebagian besar upayanya untuk pengelolaan sumber daya manusia yakni sebesar $75 \%$, peralatan atau teknologi sebesar $10 \%$, dan system perencanaan sebesar $15 \%$.

Menurut Stoner ( Sena dan Sunuharyo, 2018 ) karyawan yang bekerja dalam perusahaan harus diperlakukan secara adil dan sebaik-baiknya, dengan begitu akan dapat menumbuhkan sikap loyalitas kepada perusahaan. Selain itu, manajemen sumber daya manusia harus dapat mengetahui karakteristik individu masing-masing karyawan guna memberikan motivasi dengan cara yang tepat. Saat karyawan memiliki dorongan yang kuat dalam bekerja maka akan semakin terpacu untuk meningkatkan kontribusi dan kinerjanya kepada perusahaan. Bagi sebagian pembatik jenis pekerjaan borongan tidak 
menjadi masalah, namun dari hasil wawancara, terdapat hal yang menjadi harapan yang ingin dicapai.

Hayati dkk (2018) menyampaikan bahwa setiap pegawai mempunyai karakteristik yang berbeda-beda yang disebabkan oleh beberapa hal, misalnya latar belakang sikap, kemampuan, minat dan faktor lainnya dari pegawai itu sendiri. Keberagaman perilaku tersebut akan mempengaruhi jalannya kegiatan organisasi. Peningkatan kinerja pegawai dipengaruhi oleh beberapa faktor yang salah satunya seperti karakteristik individu pegawai, dimana karakteristik individu memiliki peran yang sangat penting dalam peningkatan kinerja pegawai. Individu membawa nilai yang melekat dalam diri yang terbentuk oleh lingkungan dimana ia tinggal, nilai - nilai tersebutlah yang nantinya dibawa dalam situasi kerja. Oleh karena itu, nilai - nilai dari setiap individu yang berbeda - beda satu dengan yang lainnya harus diketahui oleh suatu organisasi agar dapat digunakan untuk menilai pegawai yang potensial.

Selain karakteristik individu, karakteristik pekerjaan juga dapat mempengaruhi kinerja pegawai. Seorang pegawai membutuhkan keterampilan untuk menyelesaikan suatu tugas, keterampilan pegawai ditentukan oleh aktifitas yang dikerjakan dan setiap aktifitas yang berbeda membutuhkan keterampilan yang beragam. Karakteristik pekerjaan yang berbeda memerlukan keterampilan, identitas tugas dan otonomi yang berbeda pula. (Dayat,dkk,2018) berpendapat bahwa perbedaan karakteristik yang melekat pada pekerjaan memerlukan individu yang tepat sesuai dengan spesifikasi kerja yang ada. Bila masing - masing pegawai sudah mengetahui jenis pekerjaan apa yang dihadapi dan cara khusus untuk menanganinya, maka hal ini dapat mempengaruhi pekerjaanya.

Selain sumber daya manusia sebagai salah satu unsur yang sangat menentukan keberhasilan suatu organisasi, disisi lain juga sebagai makhluk yang mempunyai pikiran, perasaan, kebutuhan dan harapan-harapan tertentu. Hal ini sangat memerlukan perhatian tersendiri karena faktor-faktor tersebut akan mempengaruhi prestasi, dedikasi dan loyalitas serta kecintaan terhadap pekerjaan dan organisasinya (Rivai, 2010).

Pekerja rumahan adalah seseorang yang melakukan pekerjaan didalam rumahnya atau tempat lain sesuai dengan pilihannya selain dari tempat produksi/industri dengan proses upah yang didapatkan dari hasil produk atau jasa yang dinginkan oleh pemberi kerja tanpa memandang siapa yang memasok peralatan, bahan atau yang lain. Pada umumnya, mereka dibayar setiap hari tanpa manfaat dan tidak ada kepastian keberlanjutan kerja. Sistem kerja yang seperti itu merupakan sistem kerja dengan putting out system (POS) 
yang pelaksanaan produksi dilakukan diluar tempat, tidak di dalam industri itu melainkan dibawa kerumah (Fajerman, 2013)

Kondisi tersebut selaras dengan situasi pada pekerja batik yang banyak dilakukan oleh para perempuan, seiring dengan meningkatnya peran wanita yang bekerja dan dapat berperan untuk meningkatkan kedudukan keluarga atau membantu mencukupi kebutuhan keluarga namun tetap masih melakukan pekerjaan dan tanggung jawabnya sebagai ibu rumah tangga. Para pekerja ini membawa pekerjaaanya dan alat-alatnya yang seharusnya dikerjakan di pabrik/ tempat produksi dibawa kerumah. Pada umumnya sistem pekerjaan ini dilakukan oleh pengusaha UMKM karena dinilai lebih efisien dan tidak terikat kontrak dengan para pekerja.

Pekerja Putting Out System banyak dilakukan oleh wanita, menurut (Kartono, 2007) wanita adalah individu berjenis kelamin berbeda secara fisiologis yang tumbuh sejak lahir, kemudian diperkuat oleh sistem kebudayaan yang sudah ada, khususnya oleh adat istiadat, metode sosial-ekonomi dan akibat sistem pendidikan. Menurut Mantra 2004 ( Nilakusmawati, Susilawati, 2012), bekerja yaitu suatu aktivitas kegiatan untuk menciptakan atau membantu mendapatkan barang atau jasa dengan maksud untuk memperoleh penghasilan berbentuk uang dan atau barang, dalam kurun waktu (time reference) yang ditentukan. Kerja rumahan (home work) merupakan jenis kerja informal yang dilakukan dirumah dalam lingkungan rumah tangga (Kartini dan Maryati, 2020). Dari penjabaran diatas, disimpulkan dari beberapa pengertian diatas, wanita pekerja putting out system adalah wanita yang bekerja di rumah untuk menghasilkan suatu barang atau jasa dengan maksud untuk memperoleh penghasilan berupa uang. Pekerjaan putting out system ini memiliki karakteristik yang membedakan dengan pekerjaan lain. Rita Rahmawati, dkk (2012) menyatakan bahwa karakteristik pekerja rumahan atau putting out system yaitu sistem untuk mengatur, mengendalikan dan memobilisasi proses produksi dan hubungan produksi dari bahan mentah menjadi barang jadi yang dilakukan di luar perusahaan. Pekerjaan dari perusahaan dibawa dan dikerjakan oleh pekerja ditempat yang dipilih sendiri, biasanya di rumah pekerja atau disekitar rumah pekerja. Dalam sistem ini, pekerja dikategorikan sebagai pekerja rumahan yaitu, tenaga kerja yag menerima pekerjaan dari pengusaha tanpa ikatan kerja formal, membawa dan mengerjakannya dirumah, tanpa supervisi, menyediakan sendiri fasilitas kerja, menanggung sendiri resiko produksi serta menerima upah kerja. Pekerjaan rumahan tidak memiliki kuasa untuk menentukan pemakaian dan memasarkan 
produk dipasar. Pada umumnya wanita yang bekerja dengan putting out system telah berusia diatas 40 tahun.

Keadaan ini menjadikan sumber daya manusia sebagai aset yang harus ditingkatkan efisiensi dan produktivitasnya. Untuk mencapai hal tersebut, maka kedua belah pihak yaitu pembatik dan juragan atau pemberi kerja harus mampu menciptakan kondisi yang dapat mendorong dan memungkinkan karyawan untuk mengembangkan dan meningkatkan kemampuan serta keterampilan yang dimiliki secara optimal.

Pemaparan diatas menunjukkan bahwa pentinganya diketahui karakteristik individu, karakteristik pekerjaan dan motivasai kerja guna tercapainya kinerja yang optimal, namun keadaan di lapangan dengan berbeda. Hal ini penting untuk diteliti lebih lanjut supaya tercipta kondisi yang saling menguntungkan antara pemberi kerja dan pekerja pada sektor batik.

\section{Metode}

Metode penelitian ini menggunakan pendekatan kuantitatif. Populasi yang digunakan dalam penelitian ini adalah pembatik yang menggunakan sistem kerja borongan ( putting out system ). Sampel dalam penelitian ini berjumlah 66 orang dengan teknik sampling insidental, yaitu teknik penentuan sampel berdasarkan kebetulan atau siapa saja yang secara kebetulan/insidental bertemu dengan peneliti dimana orang yang kebetulan ditemui cocok sebagai sumber data (Sugiyono, 2018). Metode pengumpulan data menggunakan skala karakteristik pekerjaan, skala karakteristik individu, skala motivasi kerja, dan skala kinerja karyawan. Analisis data diolah menggunakan program SmartPLS 3.0 dengan teknik analisis jalur karena analisis jalur dapat menguji hubungan langsung antar variabel maupun hubungan tidak langsung antar variabel dalam model (Ghozali \& Latan, 2015).

\section{Hasil}

\section{Validitas}

Validitas diskriminan dinilai berdasarkan crossloading pengukuran dengan konstruk. Jika korelasi konstruk dengan item pengukuran lebih besar daripada ukuran konstruk lainnya maka konstruk laten memprediksi ukuran pada blok mereka lebih baik daripada ukuran pada blok lainnya (Ghozali, 2014). Rule of thumb untuk menilai validitas diskriminan yaitu dengan melihat nilai crossloading untuk setiap variabel harus lebih dari 0.7 (Ghozali \& Latan, 2015). 
Philanthropy Journal of Psychology

Vol 5 Nomor 1 (2021), 218-230

ISSN 2580-6076 (Print), ISSN 2580-8532 (Online)

Tabel 1. Validitas Diskriminan Variabel Penelitian

\begin{tabular}{llllll}
\hline & $\begin{array}{l}\text { Karakteristik } \\
\text { Individu }\end{array}$ & $\begin{array}{l}\text { Karakteristik } \\
\text { Pekerjaan }\end{array}$ & $\begin{array}{l}\text { Kinerj } \\
\text { a }\end{array}$ & $\begin{array}{l}\text { Motivasi } \\
\text { Kerja }\end{array}$ \\
\hline $\begin{array}{l}\text { Karakteristik } \\
\text { Individu }\end{array}$ & & $\mathbf{0 . 7 6 8}$ & & & \\
\hline $\begin{array}{l}\text { Karakteristik } \\
\text { Pekerjaan }\end{array}$ & 0.291 & $\mathbf{0 . 7 5 9}$ & & \\
\hline Kinerja & 0.573 & 0.548 & $\mathbf{0 . 7 7 8}$ & \\
\hline Motivasi Kerja & 0.560 & 0.544 & 0.738 & $\mathbf{0 . 7 7 9}$ \\
\hline
\end{tabular}

Berdasarkan tabel diatas, semua variabel dinyatakan valid karena nilai korelasi dari suatu variabel lebih besar daripada nilai korelasi variabel tersebut terhadap variabel lainnya.

\section{Reliabilitas}

Uji reliabilitas dilakukan untuk membuktikan akurasi, konsistensi dan ketepatan instrumen dalam mengukur konstruk. Pengukuran reliabilitas dapat dilakukan dengan dua cara yaitu Cronbach's Alpha dan Composite Reliability. Rule of thumb untuk menilai composite reliability yaitu nilai composite reliability harus lebih besar dari 0.7 untuk penelitian yang bersifat confirmatory dan 0.6 - 0.7 untuk penelitian yang bersifat explanatory, sedangkan nilai Cronbach's Alpha harus lebih besar dari 0.7 untuk penelitian yang bersifat confirmatory dan 0.6 untuk penelitian yang bersifat explanatory (Ghozali \& Latan, 2015).

Tabel 2. Reliabilitas Variabel Penelitian

\begin{tabular}{lcccc}
\hline & $\begin{array}{l}\text { Cronbach's } \\
\text { Alpha }\end{array}$ & rho_A & $\begin{array}{l}\text { Composite } \\
\text { Reliability }\end{array}$ & $\begin{array}{l}\text { Average Variance } \\
\text { Extracted (AVE) }\end{array}$ \\
\hline $\begin{array}{l}\text { Karakteristik } \\
\text { Individu }\end{array}$ & 0.950 & 0.953 & 0.956 & 0.590 \\
\hline $\begin{array}{l}\text { Karakteristik } \\
\text { Pekerjaan }\end{array}$ & 0.969 & 0.970 & 0.971 & 0.576 \\
\hline Kinerja & 0.956 & 0.957 & 0.961 & 0.605 \\
\hline Motivasi Kerja & 0.954 & 0.954 & 0.959 & 0.607 \\
\hline
\end{tabular}

Berdasarkan tabel diatas, semua variabel dinyatakan reliabel karena nilai composite reliability lebih besar dari 0,7 atau bisa juga cronbach's alpha lebih besar dari 0,6

\section{Uji Hipotesis}

Uji hipotesis dalam penelitian ini diproses menggunakan SmartPLS 3.0. Teknik yang digunakan adalah teknik analisis jalur. Teknik ini merupakan pengembangan dari analisis regresi berganda. Tujuan dari pemilihan teknik analisis jalur adalah karena penelitian ini menggunakan variabel intervening. Analisis jalur dapat menguji hubungan langsung antar 
ISSN 2580-6076 (Print), ISSN 2580-8532 (Online)

variabel maupun hubungan tidak langsung antar variabel dalam model (Ghozali \& Latan, 2015).

\section{Gambar 1}

Model Hasil Penelitian ( P Values )

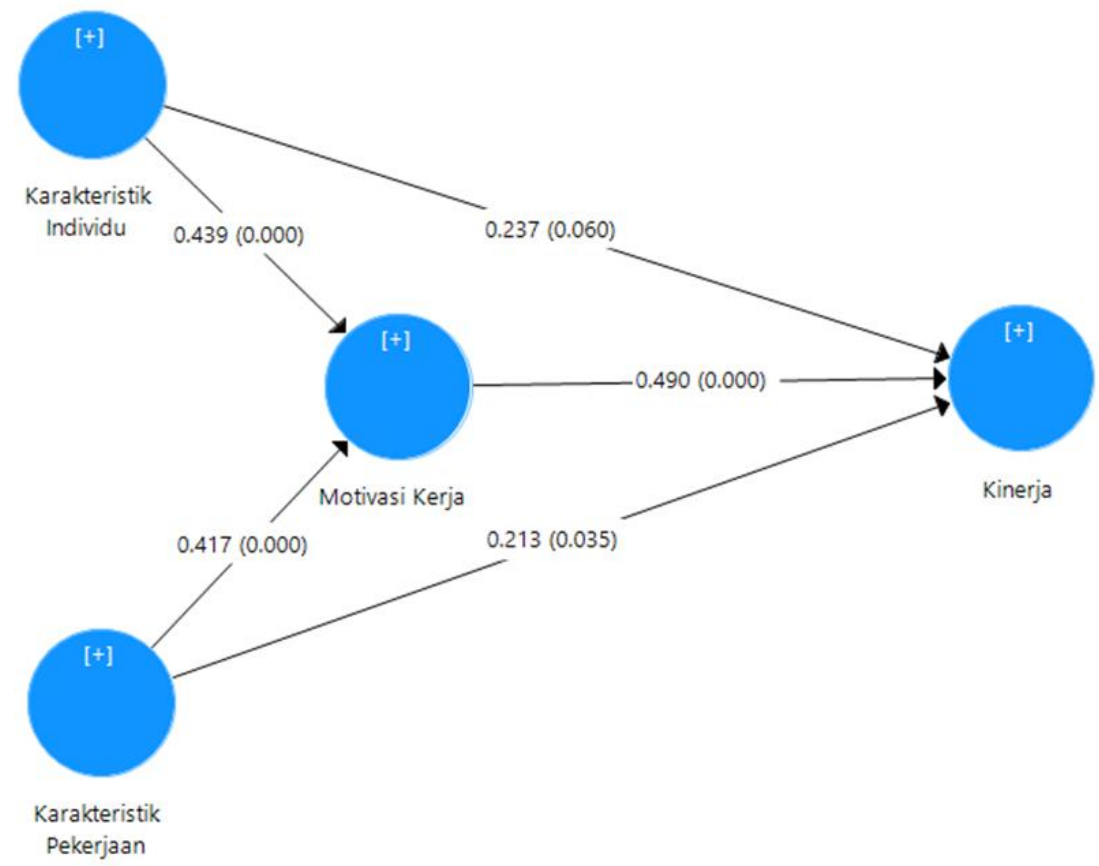

Berikut adalah tabel rincian hasil uji hipotesis yang telah diolah menggunakan program SmartPLS 3.0 :

Tabel 3. Hasil Pengujian Hipotesis

\begin{tabular}{lccccc}
\hline & $\begin{array}{l}\text { Original } \\
\text { Sample (0) }\end{array}$ & $\begin{array}{l}\text { Sample } \\
\text { Mean (M) }\end{array}$ & $\begin{array}{l}\text { Standard } \\
\text { Deviation (STDEV) }\end{array}$ & $\begin{array}{l}\text { T Statistics } \\
(\mid \text { OSTDEV|) }\end{array}$ & $\begin{array}{l}\text { Palue } \\
\text { S }\end{array}$ \\
\hline $\begin{array}{l}\text { K. Individu } \rightarrow \\
\text { Kinerja }\end{array}$ & 0.237 & 0.237 & 0.126 & 1.882 & 0.060 \\
\hline $\begin{array}{l}\text { K. Individu } \rightarrow \\
\text { Motivasi Kerja }\end{array}$ & 0.439 & 0.433 & 0.105 & 4.198 & 0.000 \\
\hline $\begin{array}{l}\text { K. Pekerjaan } \rightarrow \\
\text { Kinerja }\end{array}$ & 0.213 & 0.210 & 0.101 & 2.119 & 0.035 \\
\hline $\begin{array}{l}\text { K. Pekerjaan } \rightarrow \\
\text { Motivasi Kerja }\end{array}$ & 0.417 & 0.416 & 0.104 & 4.006 & 0.000 \\
\hline $\begin{array}{l}\text { Motivasi Kerja } \rightarrow \\
\text { Kinerja }\end{array}$ & 0.490 & 0.487 & 0.138 & 3.541 & 0.000 \\
\hline
\end{tabular}

Berdasarkan tabel diatas, karakteristik individu berpengaruh positif dan signifikan terhadap motivasi kerja karena nilai t statistics sebesar 4,198 dimana lebih besar dari t tabel = 1,96 dan juga $p$ values sebesar 0,000 dimana lebih kecil dari 0,05. Hal tersebut menunjukkan bahwa $\mathrm{H} 1$ diterima. 
Karakteristik Pekerjaan berpengaruh positif dan signifikan terhadap Motivasi Kerja karena nilai t statistics sebesar 4,006 dimana lebih besar dari t tabel = 1,96 dan juga $\mathrm{p}$ values sebesar 0,000 dimana lebih kecil dari 0,05. Hal tersebut menunjukkan bahwa H2 diterima.

Motivasi Kerja berpengaruh positif dan signifikan terhadap Kinerja karena nilai $t$ statistics sebesar 3,541 dimana lebih besar dari t tabel =1,96 dan juga p values sebesar 0,000 dimana lebih kecil dari 0,05. Hal tersebut menunjukkan bahwa motivasi kerja mampu menjadi mediasi karakteristik pekerjaan dan karakteristik individu terhadap kinerja sehingga $\mathrm{H} 3$ diterima.

Karakteristik Individu tidak berpengaruh signifikan terhadap Kinerja karena nilai t statistics sebesar 1,882 dimana lebih kecil dari t tabel $=1,96$ dan juga $p$ values sebesar 0,060 dimana lebih besar dari 0,05. Hal tersebut menunjukkan bahwa H4 ditolak.

Karakteristik Pekerjaan berpengaruh positif dan signifikan terhadap Kinerja karena nilai t statistics sebesar 2,119 dimana lebih besar dari t tabel $=1,96$ dan juga $p$ values sebesar 0,035 dimana lebih kecil dari 0,05. Hal tersebut menunjukkan bahwa H5 diterima.

\section{Diskusi}

\section{Pengaruh Karakteristik Individu terhadap Motivasi Kerja}

Hasil analisis data menunjukkan bahwa karakteristik individu memiliki pengaruh positif dan signifikan terhadap motivasi kerja. Hasil tersebut menunjukkan bahwa disaat pembatik merasa memiliki kemampuan dan minat yang sesuai dengan pekerjaan yang dijalani, sikap yang baik saat bekerja, dan kebutuhannya terpenuhi, maka akan tercipta motivasi kerja yang tinggi untuk bekerja mendapatkan sesuatu sesuai dengan kebutuhannya secara optimal.

Hal ini sesuai dengan teori yang dikemukakan oleh Stoner (1986:87), menjelaskan bahwa terdapat tiga faktor yang memengaruhi motivasi kerja karyawan, yang meliputi perbedaan karakteristik individu, karakteristik pekerjaan, dan situasi pekerjaan. Hasil penelitian ini mendukung penelitian sebelumnya yang dilakukan oleh Oktafiah, (2017) yang menyatakan adanya pengaruh yang signifikan antara Karakteristik Individu terhadap Motivasi Kerja Karyawan.

\section{Pengaruh Karakteristik Pekerjaan terhadap Motivasi Kerja}

Hasil analisis data menunjukkan bahwa karakteristik pekerjaan memeiliki pengaruh positif dan signifikan terhadap motivasi kerja. Hal tersebut menunjukkan bahwa meskipun sebagai pekerja borongan dengan sistem putting out mereka mengetaui secara 
detail tugas dari pekerjaan yang akan dijalani, merasa dirinya mampu melaksanakan dan meyelesaikan pekerjaan dan bertanggungjawab atas pekerjaan yang diberikan. Pembatik yang memahami mengenai karakteristik pekerjaannya akan semakin termotivasi dan memiliki dorongan yang kuat untuk bekerja lebih giat lagi, sehingga kualitas yang diharapkan oleh juragan dapat tercapai. Hal ini didukung oleh teori yang dikemukakan oleh Stoner (1986:87-88). Karakteristik pekerjaan atau job characteristic adalah atribut dari tugas yang meliputi besarnya tanggungjawab, variasi tugas, dan sejauh mana pekerjaan itu sendiri memberikan kepuasan. Kiranya, pekerjaan yang secara intrinsik memberikan kepuasan akan lebih memotivasi bagi banyak orang daripada pekerjaan yang tidak.

Hasil penelitian ini juga mendukung hasil penelitian sebelumnya yang dilakukan oleh Oktafiah, (2017) yang menyatakan adanya pengaruh yang signifikan antara Karakteristik Pekerjaan terhadap Motivasi Kerja Karyawan

\section{Pengaruh Motivasi Kerja terhadap Kinerja}

Hasil analisa diatas menunjukkan bahwa motivasi kerja memiliki pengaruh positif dan signifikan terhadap kinerja. Hasil tersebut menunjukkan bahwa pembatik yang memiliki motivasi tinggi saat melakukan pekerjaannya akan memicu keinginan untuk berkembang dan meningkatkan potensi yang dimilikinya. Hal ini dapat memotivasi pembatik untuk bekerja lebih baik dan lebih produktif sehingga hasil pekerjaannya akan meningkat dan berkualitas.

Hal ini didukung oleh teori yang dikemukakan oleh Kreitner dan Kinicki (2011:205), Motivasi dapat dipastikan mempengaruhi kinerja, walaupun bukan satu - satunya faktor yang membentuk kinerja.

\section{Pengaruh Karakteristik Individu terhadap Kinerja.}

Hasil analisis data menunjukkan bahwa karakteristik individu tidak memiliki pengaruh positif dan signifikan terhadap kinerja. Hasil tersebut didasarkan pada respon pada pernyataan pada indikator sikap dan nilai memiliki respon yang tinggi, namun pada indikator minat dan kemampuan memiliki respon yang rendah, hal ini kemungkinan disebabkan oleh jenis pekerjaan yang monoton sehingga membuat pembatik merasa bosan dengan pekerjaannya.

Keinginan untuk melakukan hal lain selain membatik merupakan pengaruh terhadap minat yang tidak sesuai dengan para pembatik, sistem kerja yang terputus juga menjadi faktor yang memengaruhi karena tidak adanya interaksi sosial antara juragan, rekan sekerja mereka cenderung melakukan pekerjaannya sendiri-sendiri sehingga perasaan 
bosan dan keinginan untuk melakukan hal lain tinggi. Indikator kemampuan juga mendapatkan respon rendah, hal ini disebabkan karena tidak adanya tantangan untuk melakukan hal lain, yang dilakukan oleh pembatik hanya satu jenis tugas saja, misal meng-klowong, nembok motif dan me-nglorod.

Hasil penelitian ini sesuai dengan penelitian Musa Djamaludin (2009) menjelaskan bahwa karaktersitik individu tidak memiliki pengaruh terhadap kinerja pegawai.

\section{Pengaruh Karakteristik Pekerjaan terhadap Kinerja}

Hasil analisis data menunjukkan bahwa karakteristik pekerjaan memiliki pengaruh positif dan signifikan terhadap kinerja. Hal ini menunjukkan bahwa pada saat tingkat kesesuaian pekerja khususnya pembatik memahami tentang karakteristik pekerjaan yang sedang dilakukannya semakin baik maka akan berdampak positif juga terhadap motivasi kerja yang dimiliki. Pembatik yang mengetahui semua detail tugas dari pekerjaan yang dijalani, merasa dirinya mampu melaksanakan setiap pekerjaan maupun tanggungjawab yang diberikan, serta mengetahui berbagai macam hal yang berhubungan dengan karakteristik pekerjaannya maka akan semakin memiliki kepercayaan diri yang tinggi atas pekerjaan yang dilakukan dan memicu dorongan yang kuat untuk bekerja keras sehingga kinerjanya dapat meningkat.

Hal ini didukung oleh teori yang dikemukakan oleh Robbins dan Coulter (2010:119120), Karakteristik pekerjaan juga dapat mempengaruhi kinerja, seperti keragaman ketrampilan, identitas tugas, signifikasi tugas, otonomi, dan umpan balik. Hasil penelitian ini juga mendukung penelitian sebelumnya yang dilakukan oleh Kasih, (2013).

\section{Simpulan}

Berdasarkan hasil penelitian yang telah dilakukan, maka kesimpulan yang dapat diambil dari penelitian ini adalah karakteristik individu berpengaruh positif dan signifikan terhadap motivasi kerja; karakteristik pekerjaan berpengaruh positif dan signifikan terhadap motivasi kerja; motivasi kerja berpengaruh positif dan signifikan terhadap kinerja; karakteristik individu tidak berpengaruh signifikan terhadap kinerja; dan karakteristik pekerjaan berpengaruh positif dan signifikan terhadap kinerja. Sehingga dapat disimpulkan bahwa untuk mendapatkan kinerja yang memuaskan pada pembatik putting out system dapat dilakukan dengan memberikan motivasi yang sesuai dengan karakteristik individu dan karakteristik pekerjaan. 


\section{Saran}

Berdasarkan penelitian yang telah dilakukan diketahui bahwa karakteristik individu, karakteristik pekerjaan dan motivasi kerja memeiliki pengaruh yang besar terhadap kinerja. Bagi Pembatik disarankan bahwa berdasarkan hasil yang rendah pada minat karena pembatik telah melakukan pekerjaannya sangat lama, perlu melakukan regenerasi kepada penerusnya, hal ini selaras dengan perlunya peningkatan pada kemampuan melakukan pekerjaan lainnya meskipun masih dalam skala membatik, peningkatan kemampuan dapat dilakukan melalui pelatihan sehingga pembatik mampu melakukan rangkaian pekerjaan dalam proses membatik. Bagi Pelaku Usaha dan Industri Batik disarankan bahwa meskipun tidak ada ikatan formal dengan pembatik borongan ini, namun sebagai juragan perlu memberikan motivasi dan memberikan dorongan untuk peningkatan kemampuan para pembatik. Potensi lain yang dimiliki pembatik dapat memberikan rasa percaya diri sehingga hasil kerja yang berkualitas, sesuai standart industri dapat tercapai. Bagi Peneliti selanjutnya yang tertarik dengan tema motivasi kerja dan kine Selain hal tersebut, pemilihan sampel juga perlu diperhatikansupaya proses pengumpulan data dapat berjalan lancar.

\section{Daftar Pustaka}

A'syah dan Suhaeli. (2020).Pengaruh Kecerdasan Spiritual dan Komitmen Organisasi Terhadap Kinerja Karyawan. Jurnal Business and Economics Conference in Utilization of Modern Technology

Djamaludin,Musa.2009.Pengaruh Komitmen Organisasional, Pengembangan Karir,Motivasi Kerja, dan Karaktersitik Individual Terhadap Kepuasan Kerja dan Kinerja Pegawai Pemerintah Kabupaten Halmahera Timur. Alumni Doktor program pasca sarjana Universitas 17 Agustus 1945 : Surabaya

Dayat, Wahyu, dan Wahyuni. (2018). Pengaruh Karakteristik Individu dan Karakteristik Pekerjaan terhadap Kinerja Pegawai. Jurnal Bisnis dan Pembangunan. Vol. 7. No. 1.

Dangler,Jamie Faricella,1985. Industrial Homework in The Modern Worls Economy.

Fahmi, I. (2015). Pengantar Manajemen Sumberdaya Manusia Konsep \& Kinerja. Jakarta: Mirta Wacana Media.

Fajerman. (2013). Review of the Regulatory Framework for Homeworkers in Indonesia. Jakarta: International Labour Organization.

Handoko, T. Tani, (2000). Manajemen Edisi 2, Yogyakarta: BPFE.

Kartono, K. (2007). Psikologi Wanita Jilid I (Mengenal Gadis Remaja dan Wanita Dewasa). 
Kasih, Prisky Amalia Cendera Kasih. (2013). Pengaruh Karakteristik Biografis dan Karakteristik Pekerjaan terhadap Kinerja (Penelitian Pada Karyawan Bagian Back Office PT Bank Mandiri (Persero) Tbk. Malang: Fakultas Ilmu Administrasi Bisnis, Universitas

Martoyo, Susilo, (1992). Manajemen Sumber Daya Manusia, Yogyakarta: BPFE.

Mangkunegara, A. P. (2009). Manajemen Sumber Daya Manusia Perusahaan. Bandung: PT Remaja Rosdakarya Offset

Moses, R.M., Astuti, E.S., dan Hakam, M.S. (2014). Pengaruh Karakteristik Individu dan Karakteristik Pekerjaan terhadap Prestasi Kerja Karyawan. Jurnal Administrasi Bisnis (JAB). Vol. 12. No. 01, p. 1 - 10

Oktafiah, Risa. (2017). Pengaruh Karakteristik Individu dan Karakteristik Pekerjaan Terhadap Motivasi Kerja dan Prestasi Kerja Karyawan (Studi Pada Karyawan PT Pembangkitan Jawa Bali Unit Pembangkitan Gresik. Malang: Fakultas Ilmu Administrasi, Universitas Brawijaya

Panggabean, M. S, (2004). Manajemen Sumber Daya Manusia, Bogor: Ghalia Indonesia.

Robbins, Stephen P., Judge, Timothy A. (2007). Organization Behavior, Pearson Prentice Hall.

Robbins, Stephen P., Judge, Timothy A. (2011). Organizational behavior (14th ed.). New Jersey: Prentice Hall.

Robbins, S. P. \& Mary C. (2010). Manajemen. Jilid 2. Jakarta: Erlangga

Sutrisno, E. (2012). Sumber Daya Manusia. Surabaya: Gramedia.

Subyantoro, A. (2009). Karakteristik Individu, Karakteristik Pekerjaan, Karakteristik Organisasi dan Kepuasan Kerja Pengurus yang Dimediasi oleh Motivasi Kerja. Jurnal Manajemen dan Kewirausahaan. Vol. 11, No. 01, p. 11 - 19.

Sugito, P., dan Nurjannah, S. (2004). AnalisisPengaruh Karakteristik Individu, Pekerjaan dan Organisasi terhadap Kinerja Karyawan Perusahaan Daerah Air Minum Kota Malang. Jurnal Penelitian. Vol. XVI. NO 1.

Sugiyono. (2009). Metode Penelitian Kuantitatif, Kualitatif dan Research \& Development. Bandung: Alfabeta.

Stoner, J. A. F. (1986). Manajemen. Jilid 2, Edisi Kedua. Alih Bahasa Gunawan Hutahuruk. Jakarta: Erlangga

Thoha, M. (2015). Perilaku Organisasi: Konsep Dasar dan Aplikasinya. Jakarta: PT Raja Grafindo Persada

Tivani. (2013). Pengaruh Karakteristik Individu dan Karakteristik Pekerjaan Terhadap Motivasi Kerja Karyawan (Penelitian Pada Karyawan Radar Malang). Malang: Fakultas Ilmu Administrasi Bisnis, Universitas Brawijaya 
Widanarni, D., Irwansyah dan Utomo, S. (2015). Pengaruh Karakteristik Individu, Karakteristik Pekerjaan dan Karakteristik Organisasi Terhadap Kepuasan Kerja Karyawan. Jurnal Bisnis dan Pembangunan. Vol. 3, No. 1, p. 35 - 41.

Wijaya, H. R. (1995). Perlindungan Sosial Pada Perempuan Pekerja Rumahan: Riset Aksi Pemberdayaan Perempuan Untuk Mengubah Kondisi Kerjanya. In T. O. Ihromi (Ed.), Kajian Wanita dalam Pembangunan (pp. 401-429). Jakarta: Yayasan Obor Indonesia 